\title{
Signaling Firm Performance Through Corporate Voluntary Disclosure
}

Amal Hamrouni, La Rochelle Business School \& CAEPEM University of Perpignan via Domitia, France Anthony Miloudi, La Rochelle Business School \& CRIEF University of Poitiers, France

Ramzi Benkraiem, Audencia Nantes School of Management, France

\begin{abstract}
The present study empirically investigates the link between corporate voluntary disclosure and firm performance. The empirical analyses show a positive relationship between disclosure indexes and firm performance proxies. They provide evidence that the level of voluntary information disclosed in annual reports plays a significant signaling role of firm performance. However, the extent of this role depends on the nature of the voluntary disclosure, i.e. strategic, financial or corporate governance information.
\end{abstract}

Keywords: Voluntary Disclosure; Signaling Theory; Firm Performance; Data Envelopment Analysis

\section{INTRODUCTION}

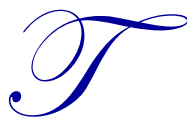

his study examines the relationship between corporate voluntary disclosure and firm performance. According to signaling theory (Spence, 1973), the main objective of firm disclosure is to inform analysts and investors of about the firm quality and value. In this regard, Verrecchia (1983) suggests that corporate disclosure helps analysts and investors to predict future earnings, as corporate managers have to disclose value-relevant information.

Numerous studies demonstrate that the informativeness of voluntary disclosure reduces the cost of capital (Francis et al., 2008; Karamanou and Nishiotis, 2009; Dhaliwal et al., 2011) and increases the firm value (Lajili and Zeghal, 2006; Banghøj and Plenborg, 2008; Cheung et al., 2010; Hassan and Mohd-Saleh, 2010; Al-Akraa and Jahangir-Ali, 2012). Some other studies especially focus on corporate voluntary disclosure in annual reports. These reports are the main documents published by firms and are generally used by stakeholders to assess firm performance (Lang and Lundholm, 1993; Banghøj and Plenborg, 2008; Hassan et al., 2009; Uyar and Kiliç, 2012). Hence, previous research on voluntary disclosure demonstrates that relevant corporate information reveals firm value. The present paper extends this previous research and investigates whether the extent of voluntary disclosure in annual reports signalizes firm performance.

For the empirical analyses, we use panel data of 1074 firms-years listed on the Euronext Paris stock exchange. Firstly, we deploy a non-parametric approach to assess firm performance. In particular, we rely on data envelopment analysis (DEA) to measure the firm ability to maximize its value (output) given a set of determinants (inputs). Secondly, we employ a parametric approach to explain firm performance proxies. We consider the estimated efficiency scores obtained from the DEA approach as a dependent variable. In parallel, we use disclosure indexes, which measure the level of voluntary disclosure in annual reports, as independent variables.

The empirical findings show a positive relationship between disclosure indexes and performance measures. They provide evidence that the level of voluntary information disclosed in annual reports plays a significant signaling role of firm performance. However, the extent of this role depends on the nature of the voluntary disclosure, i.e. strategic, financial or corporate governance information. The findings presented and discussed in this article should provide useful insights for academics as well as practitioners. As far as we know, this study is one of the first, especially in the French context, to consider the multidimensionality of firm performance when investigating whether the extent of voluntary disclosure signalizes corporate performance. Thus, the methodological 
approach and the empirical results of this research enrich the existing literature on the signaling role of corporate voluntary disclosure, relying on an innovative DEA non-parametric approach to assess firm performance.

The remainder of this paper consists of four sections. Section 2 presents the theoretical framework. Section 3 explains the methodology. Section 4 presents and discusses the results and Section 5 serves as a conclusion.

\section{THEORETICAL FRAMEWORK}

According to signaling theory (Spence, 1973), the primary objective of corporate disclosure is to inform analysts and investors about the firm quality and value. This suggests that voluntary disclosure decisions lead to the reporting of relevant information about firm performance. Based on these theoretical suggestions, prior studies have attempted to empirically examine the relevance of corporate voluntary disclosure.

Several studies evidence the relevance of corporate voluntary disclosure by its effect on the cost of capital. They point out that firms which have increased the level of voluntary disclosure show a lower cost of capital (Botosan, 1997; Piotroski, 1999; Verrecchia, 2001; Botosan and Plumlee, 2002). In this regard, Gietzmann and Ireland (2005), Espinosa and Trombetta (2007) and Francis et al. (2008) find a negative association between voluntary disclosure and the cost of capital. Some other studies examine the relevance of corporate voluntary disclosure through its effect on the firm value (Lajili and Zeghal, 2006; Cheung et al., 2010; Hassan and MohdSaleh, 2010; d'Al-Akraa and Jahangir-Ali, 2012). They evidence the existence of a positive relationship between voluntary disclosure and the firm value. Hence, they highlight the significant signaling role of corporate voluntary disclosure. For instance, Hassan et al. (2009) specify that corporate voluntary disclosure mitigates uncertainty surrounding firm growth perspectives and facilitates share trading. Consequently voluntary disclosure is likely to affect the firm value. Based on the arguments of the signaling theory and the empirical results of prior studies, we anticipate that corporate voluntary disclosure may be considered as a signaling tool revealing firm performance.

An important element of debate in finance research is how to assess firm performance. Performance evaluation through the income statement is the most common approach. Several criticisms have been addressed to the use of accounting measures of performance (Benston, 1985). Market evaluation through for instance market-tobook ratio or Tobin's Q could be presented as alternative estimates of firm performance. However, market values depend on investor confidence and on other factors outside the direct control of firms (Nanka-Bruce, 2009). Thus, market values as measures of performance are not entirely attributable to firm specific characteristics (Nanka-Bruce, 2009).

In this study, we deploy another alternative multidimensional measure of performance to counteract such difficulties. This measure of performance is based on technical efficiency through both parametric and nonparametric approaches. Note that Technical efficiency relates to the success of firms to produce maximum outputs from a set of inputs under a given production technology (Nanka-Bruce, 2009). Some previous papers have linked technical efficiency to a number of corporate governance aspects, such as board of directors and ownership structure. Nevertheless, to the best of our knowledge, no study has associated this alternative measure of performance with corporate disclosure policy. To summarize, this study aims explicitly to investigate the link between the level of corporate voluntary disclosure indexes and firm multidimensional performance proxies.

\section{METHODOLOGY}

\section{Estimating Firm Performance Using Data Envelopment Analysis (DEA)}

In this paper, we measure multidimensional firm performance using a non-parametric approach of data envelopment analysis (DEA). In this approach, each firm represents a unique decision making unit (DMU). Based on rigorous linear mathematical programming, the method focuses on the observed data of each DMU. This method makes it possible to draw conclusions based on efficiency comparisons with peers, and gives indications regarding needed policy changes (Charnes et al., 1994). In other words, it distinguishes inefficient DMUs from efficient ones based on whether or not they lie on the efficient frontier of the possibility set. This set is composed of all feasible input-output combinations with a production technology that transforms a vector of $N$ inputs 
$x=\left(x_{1}, \ldots, x_{N}\right) \in \mathfrak{R}_{+}^{N}$ into a vector of $P$ outputs $y=\left(y_{1}, \ldots, y_{P}\right) \in \mathfrak{R}_{+}^{P}$. This possibility set $\mathrm{T}$ can be formulated as follows:

$$
\mathrm{T}=\left\{(x, y) \in \mathfrak{R}_{+}^{N+P}: x \in \mathfrak{R}_{+}^{N} \text { can produce } y \in \mathfrak{R}_{+}^{P}\right\}
$$

We analyze the relative performance using an output-oriented projection model, producing the largest possible outputs from a given set of inputs. Efficient firms are those that succeed in using minimum inputs to produce maximum outputs. Concretely, we measure firm performance via its value-creation capacity and, in particular, we examine corporate managers' ability to maximize firm value with an optimal allocation of the same inputs. In other words, we examine whether operating and investment decisions are optimal with regard to obtaining a higher firm value. We use firm value proxies as outputs and operating and investment policy proxies as inputs.

\section{Inputs And Outputs Selection}

The principal difficulty with the DEA approach is the choice and specification of inputs and outputs. We base our selection of inputs and outputs on prior research. We select determinants of firm value that are widely used in corporate finance. Figure 1 illustrates the modeling of firm performance. Table 1 presents the selected inputs and outputs of our DEA analysis, the variable measurements and the main corresponding references, respectively.

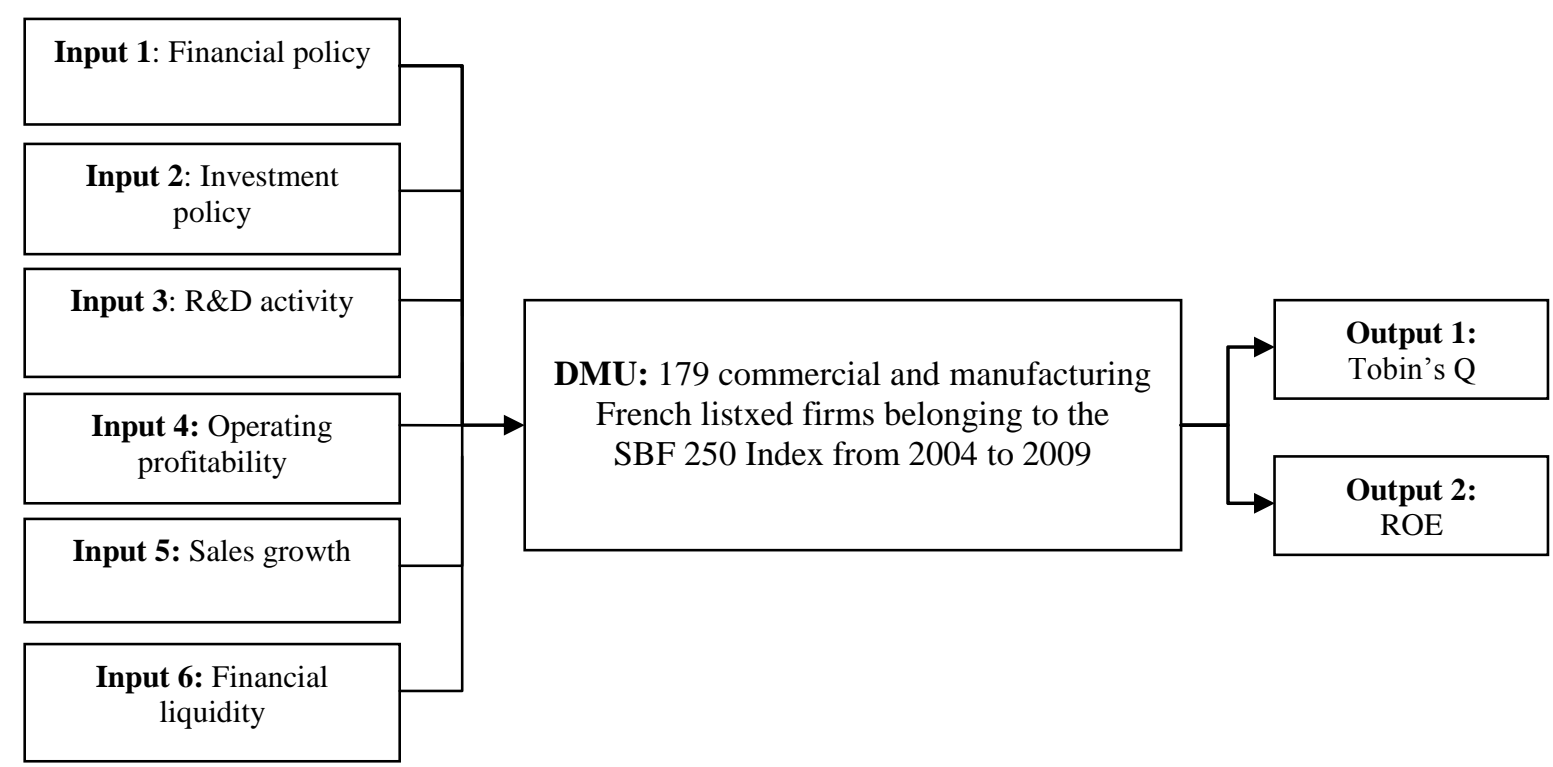

Figure 1: Firm Performance Modeling Using DEA 
Table 1: Outputs And Inputs Of The Firm Performance Analysis

\begin{tabular}{|c|c|c|}
\hline Variables & References & References \\
\hline \multicolumn{3}{|c|}{ Outputs } \\
\hline Firm value & $\begin{array}{l}\text { Tobin's } Q=\text { Market value of stock + Accounting } \\
\text { value of the total debt / Total assets }\end{array}$ & $\begin{array}{l}\text { Himmelberg et al. (1999); Holderness et al. (1999) and } \\
\text { Drobetz et al. (2004). }\end{array}$ \\
\hline $\begin{array}{l}\text { Firm } \\
\text { profitability }\end{array}$ & $\begin{array}{l}\text { Return on equity }(\mathrm{ROE})=\text { Net benefit } / \\
\text { Ownership equity }\end{array}$ & $\begin{array}{l}\text { Demsetz and Lehn (1985); Holderness and Sheehan } \\
\text { (1988); Denis and Denis (1994); Thomsen and Pedersen } \\
\text { (1996) and Li and Simerly (1998). }\end{array}$ \\
\hline \multicolumn{3}{|c|}{ Inputs } \\
\hline $\begin{array}{l}\text { Financial } \\
\text { policy }\end{array}$ & Total debt / Total assets & $\begin{array}{l}\text { Holderness et al. (1999); Short and Keasey (1999); } \\
\text { Oxelheim and Randøy (2003); Habid and Ljungqvist } \\
\text { (2005); Bailey et al. (2006) and Zarb (2007). }\end{array}$ \\
\hline $\begin{array}{l}\text { Investment } \\
\text { policy }\end{array}$ & Tangible assets / Sales & $\begin{array}{l}\text { Demsetz and Lehn (1985); Klapper and Love (2004); } \\
\text { Habid and Ljungqvist (2005) and Ammann et al. (2011). }\end{array}$ \\
\hline R\&D activity & R\&D expenses / Sales & $\begin{array}{l}\text { Demsetz and Lehn (1985); Smith and Watts (1992); Cho } \\
\text { (1998); Himmelberg et al. (1999); Habid and Ljungqvist } \\
\text { (2005); Olsen and Elango (2005) and Ammann et al. } \\
\text { (2011). }\end{array}$ \\
\hline $\begin{array}{l}\text { Operating } \\
\text { profitability }\end{array}$ & Profit before taxes / Sales & Habid and Ljungqvist (2005) and Ammann et al. (2011). \\
\hline Sales growth & Sales $_{t}-$ Sales $_{t-1} /$ Sales $_{t}$ & $\begin{array}{l}\text { Short and Keasey (1999); Olsen and Elango (2005); } \\
\text { Bailey et al. (2006); LaPointe et al. (2006); Banghpj and } \\
\text { Plenborg (2008); Hassan et al. (2009) and Ammann et al. } \\
\text { (2011). }\end{array}$ \\
\hline $\begin{array}{l}\text { Financial } \\
\text { liquidity }\end{array}$ & Free cash flow / Total assets & $\begin{array}{l}\text { Cho (1998); Thomsen and Pedersen (2000); Seifert et al. } \\
\text { (2005) and Ammann et al. (2011). }\end{array}$ \\
\hline
\end{tabular}

\section{Empirical Specification}

To test the relationship between corporate voluntary disclosure and firm performance, we deploy the logit model presented below. The dependent variable (PEFF) takes the value of 1 if a firm is located on the efficiency frontier and 0 otherwise. The voluntary disclosure level is used as an independent variable. Firm size, analyst following, dividend policy and industry are deployed as control variables.

$$
\mathrm{PEFF}_{\mathrm{it}}=\alpha_{0}+\alpha_{1} \mathrm{VD}_{\mathrm{it}}+\alpha_{2} \mathrm{SIZ}_{\mathrm{it}}+\alpha_{3} \mathrm{ANF}_{\mathrm{it}}+\alpha_{4} \mathrm{DPS}_{\mathrm{it}}+\alpha_{5} \mathrm{IND}_{\mathrm{it}}+\mu_{\mathrm{it}}
$$

Where for firm $i$ in year $t$ : VD is equal to the global disclosure index. SIZ is the logarithm of total assets. ANF is the logarithm of 1 plus the number of financial analysts. DPS is the dividend per share. IND is a dichotomous variable coded 1 if the company operates in a high-technology sector and 0 otherwise. $\mu$ is the error term.

The independent variable (VD) is the voluntary disclosure score derived from annual reports. We focus on the annual report for several reasons. Firstly, the annual report is considered as the main source of mandatory as well as voluntary disclosures, providing important information for analysts and investors (Wiseman, 1982; Rockness, 1985; Neu et al., 1998). Secondly, the level of firm disclosure is best evidenced by the amount of information contained in an annual report (Zarb, 2007). For instance, Lang and Lundholm (1993) and Holland (1998) find a high positive correlation between corporate disclosure in annual reports and other forms of disclosures. The independent variable (VD) is measured using self-constructed disclosure indexes. We develop a disclosure checklist inspired from Meek et al. (1995), Botosan (1997), Chau and Gray (2002), Eng and Mak (2003), Lim et al. (2007) and Francis et al. (2008). This checklist consists of 112 items (see Appendix) falling into four general categories, namely, strategic information (STGVD, 30 items), non-financial information (NFNVD, 35 items), financial information (FNVD, 36 items), and corporate governance information (GOVVD, 11 items). Following Cooke (1992), we conduct a content analysis to identify the needed information in annual reports. ARVD is the sum of the scores attributed to each item in the voluntary disclosure checklist. 
The Appendix presents the checklist of 112 items included in the disclosure scores. To avoid subjectivity, we consider all the disclosed items as equally important, despite the possible variability of information content from one item to another. Thus, we assign a value of 1 when a given item is disclosed and 0 otherwise. The total score is computed as the unweighted score sum of all index items.

The agency theory (Jensen and Meckling, 1976) suggests that firm size affects firm performance because of its impact on ownership structure and the resulting agency problems/conflicts of interest. Indeed, large firms generally realize scale economies which, in turn, influence firm performance (Nanka-Bruce, 2009).

Financial analysts are likely to play a significant role in reducing information asymmetry between corporate managers and investors (Healy and Palepu, 2001). Analysts select firms that are likely to have the most profitable and least risky securities (Boubaker and Labegorre, 2006). As a result, analyst following may reflect firm performance and/or quality to stock market participants. Empirical studies (Pearson, 1992; Chung, 2000; Lang et al., 2004) confirm the signaling role of analyst following. They demonstrate a positive relationship between analyst following and firm value.

According to the signaling theory, the dividend distribution is considered a signal of firm performance. Indeed, in an uncertain economic environment where external investors do not have perfect information about firm profitability, dividends are likely to inform about firm expected cash flows (Bhattacharya, 1979, 1980; Kalay, 1980; Miller and Rock, 1985).

\section{RESULTS AND DISCUSSION}

\section{Sample Selection And Descriptive Statistics}

Our initial sample consists of all SBF 250 French firms listed the on Euronext stock market from 2004 to 2009. We exclude financial and assimilated firms (SIC codes 4900-4999 and 6000-6999) because they operate in an environment where disclosure is more likely to be a result of specific legal and regulatory requirements. Furthermore, we discard all firms with missing financial or governance data. Finally, we obtain a sample 1074 firms-years (179 firms). Financial figures are obtained from Worldscope database. Corporate annual reports are downloaded from the French stock market authority (AMF) website.

Table 2 shows the descriptive statistics for the dependent and the independent variables.

Table 2: Descriptive Statistics

\begin{tabular}{|c|c|c|c|c|c|c|c|c|}
\hline Variables & $\mathbf{N}$ & Min & $25 \%$ & Mean & Median & $75 \%$ & Max & St. Dev. \\
\hline \multicolumn{9}{|c|}{ Dependent Variable } \\
\hline PEFF & 179 & 0 & 0 & 0.2672 & 0 & 1 & 1 & 0.4427 \\
\hline \multicolumn{9}{|c|}{ Independent Variables } \\
\hline ARVD & 179 & 0.0708 & 0.3438 & 0.4300 & 0.4367 & 0.5044 & 0.7122 & 0.1250 \\
\hline STGVD & 179 & 0.0333 & 0.3513 & 0.4463 & 0.4420 & 0.5440 & 0.7667 & 0.1435 \\
\hline NFNVD & 179 & 0 & 0.27 & 0.3796 & 0.3714 & 0.5091 & 0.756 & 0.1554 \\
\hline FNVD & 179 & 0 & 0.2784 & 0.3860 & 0.3618 & 0.4663 & 0.9091 & 0.1629 \\
\hline GOVVD & 179 & 0.0909 & 0.3725 & 0.5647 & 0.5455 & 0.7273 & 1 & 0.2303 \\
\hline \multicolumn{9}{|c|}{ Control Variables } \\
\hline SIZ & 179 & 8.9369 & 12.8142 & 14.1258 & 13.7865 & 15.4469 & 18.9310 & 1.9102 \\
\hline ANF & 179 & 0 & 1.6094 & 2.0673 & 2.1972 & 2.6391 & 3.5553 & 0.7386 \\
\hline DPS & 179 & 0 & 0.11 & 1.0473 & 0.6 & 1.23 & 30 & 2.2668 \\
\hline IND & 179 & 0 & 0 & 0.1955 & 0 & 0 & 1 & 0.3968 \\
\hline
\end{tabular}

The descriptive statistics show that, on average, $26.72 \%$ of our sample is located on the efficiency frontier with a standard deviation of $44.27 \%$. We can notice a divergence in the efficiency of these firms. We can also detect diversity in the extent of corporate voluntary disclosure in annual reports. The ARVD ranges from a low value of 0.0708 to a high value of 0.7122 . The mean score is 0.43 , with a standard deviation of $12.50 \%$. 


\section{Regression Results}

Table 3 presents the results of the regression model testing for the relationship between disclosure index and firm performance and controlling for firm size, analyst following, dividend policy and industry.

The findings show a positive and statistically significant relationship between the PEFF and VD (measured here by ARVD) variables. They validate our hypothesis predicting the existence of an association between the level of corporate voluntary disclosures and firm performance proxies. Hence, voluntary disclosure in annual reports plays an important signaling role. It provides relevant information explaining firm performance and quality. These findings are consistent with previous studies (e.g. Uyar and Kiliç, 2012) which have demonstrated the significance of voluntary information in revealing firm quality and value.

Table 3: Value Relevance Of The Extent Of Voluntary Disclosure In Annual Reports

\begin{tabular}{cccc}
\hline Variables & Coefficient & t-statistic & Marginal probability \\
\hline Constant & $2.9926 * * *$ & 4.623 & 0.5604 \\
\hline VD & $1.6291 * * *$ & 2.910 & 0.3051 \\
SIZ & $-0.3232 * * *$ & -6.095 & -0.0605 \\
ANF & -0.1042 & -0.832 & -0.0195 \\
DPS & 0.0197 & 0.681 & 0.0037 \\
IND & $-0.3479 *$ & -1.870 & -0.0616 \\
Pseudo $\mathbf{R}^{2}$ & & 0.0629 & \\
Log likelihood & & -584.2179 & \\
LR Chi $^{2}$ & & 78.4341 & \\
$\left(\right.$ Prob $\left.>\mathbf{C h i}^{\mathbf{2}}\right)$ & & $(0.0000)$ & \\
\hline
\end{tabular}

Further analyses show that the relevance of voluntary disclosure is not homogenous for all information categories. The PEFF variable is negatively and significantly explained by STGVD and GOVVD variables. The NFNVD variable is positively and significantly related to firm performance proxies. These findings raise the question of the extent to which each voluntary information category in annual reports reveals firm performance. Hence, corporate voluntary disclosure decisions appear to be driven by incentives and constraints. Firms may find it advantageous to disclose additional pieces of information (i.e., non-financial voluntary information). In contrast, they may find it disadvantageous to disclose relevant strategic information when they operate especially in a high competitive market. This may explain the divergence in the relevance of voluntary information categories. 
Table 4: The Relevance Of Voluntary Information Categories In Annual Reports

\begin{tabular}{|c|c|c|c|c|c|c|c|c|c|c|c|c|}
\hline Variable & Coefficient & t-statistic & $\begin{array}{c}\text { Marginal } \\
\text { prob. }\end{array}$ & Coefficient & t-statistic & $\begin{array}{c}\text { Marginal } \\
\text { prob. }\end{array}$ & \begin{tabular}{|l} 
Coefficient \\
\end{tabular} & t-statistic & $\begin{array}{c}\text { Marginal } \\
\text { prob. }\end{array}$ & Coefficient & t-statistic & $\begin{array}{c}\text { Marginal } \\
\text { prob. }\end{array}$ \\
\hline Constant & $4.0346 * * *$ & 6.128 & 0.7539 & $3.5515 * * *$ & 5.712 & 0.6668 & $3.3503 * * *$ & 5.321 & 0.6283 & $3.8429 * * *$ & 5.971 & 0.7189 \\
\hline STGVD & $-1.1838 * *$ & -2.405 & -0.2212 & & & & & & & & & \\
\hline NFNVD & & & & 0.0535 & 0.117 & 0.0101 & & & & & & \\
\hline FNVD & & & & & & & $0.7766^{*}$ & 1.780 & 0.1456 & & & \\
\hline GOVVD & & & & & & & & & & $-0.6091 * *$ & -1.982 & -0.1139 \\
\hline SIZ & $-0.3192 * * *$ & -5.990 & -0.0596 & $-0.3181 * * *$ & -5.921 & -0.0597 & $-0.3254 * * *$ & -6.114 & -0.0610 & $-0.3158 * * *$ & -5.937 & -0.0591 \\
\hline ANF & -0.0348 & -0.281 & -0.0065 & -0.0655 & -0.530 & -0.0123 & -0.0596 & -0.482 & -0.0112 & -0.0418 & -0.339 & -0.0078 \\
\hline DPS & 0.0284 & 0.977 & 0.0053 & 0.0195 & 0.675 & 0.0036 & 0.0246 & 0.844 & 0.0046 & 0.0182 & 0.628 & 0.0034 \\
\hline IND & 0.0284 & -1.340 & -0.0448 & $-0.3086^{*}$ & -1.657 & -0.0552 & $-0.316^{*}$ & -1.707 & -0.0564 & -0.2925 & -1.578 & -0.0522 \\
\hline Pseudo $^{2}$ & & 0.06066 & & & 0.0560 & & & 0.0585 & & & 0.0592 & \\
\hline $\begin{array}{l}\text { Log } \\
\text { likelihood }\end{array}$ & & -585.6201 & & & -588.5187 & & & 586.9656 & & & -586.5564 & \\
\hline $\begin{array}{l}\text { LR Chi }{ }^{2} \\
\left(\text { Prob > } \text { Chi }^{2}\right)\end{array}$ & & $\begin{array}{l}75.6298 \\
(0.0000)\end{array}$ & & & $\begin{array}{l}69.8326 \\
(0.0000)\end{array}$ & & & $\begin{array}{l}72.9656 \\
(0.0000)\end{array}$ & & & $\begin{array}{l}73.7571 \\
(0.0000)\end{array}$ & \\
\hline
\end{tabular}

\section{CONCLUSION}

This paper empirically investigated the relationship between corporate voluntary disclosure and firm performance. Based on the signaling theory, we considered corporate voluntary disclosure as a signaling instrument reporting firm performance to investors and financial analysts.

The empirical analyses were based on panel data of 1074 firms-year listed on the Euronext Paris stock market. Performance evaluation has been a critical area of research. We discussed the limits of accounting and financial performance measures and attempted to take into account the multidimensionality of firm performance. Thus, we used a non-parametric approach to measure firm performance via the technical efficiency. Using data envelopment analysis (DEA), we measured a firm ability to maximize its value (outputs) given a set of determinants (inputs). The estimated efficiency scores were used as a dependent variable. We used disclosure indexes which measure the extent of voluntary disclosure in annual reports as independent variable.

The empirical findings reveal a positive relationship between disclosure indexes and performance measures. They provide evidence that the level of voluntary information disclosed in annual reports plays a significant signaling role of firm performance. However, the extent of this role depends on the nature of the voluntary disclosure, i.e. whether it involves strategic, financial or corporate governance information. 


\section{AUTHOR INFORMATION}

Dr. Amal Hamrouni is an Assistant Professor of Accounting and Finance at La Rochelle Business School and Research Fellow at the CAEPEM - University of Perpignan via Domitia. Her main research interests concern corporate governance, voluntary disclosure and information environment. She has published several academic papers in international referred journals.

Dr. Anthony Miloudi is a Full Professor at La Rochelle Business School and researcher at the CREIF -University of Poitiers. His teaching interests have spanned the areas of corporate finance and international finance. His current research interests are twofold: entrepreneurial and behavioral finance. He has published several papers in international peer reviewed journals.

Dr. Ramzi Benkraiem is an Associate Professor of financial accounting at Audencia Nantes School of Management and member of the CFRM Research Centre. His current research interests include the value relevance of financial and accounting information. He published several academic papers in both French and international peer reviewed journals.

\section{REFERENCES}

Al-Akra, M. and Jahangir-Ali, M. (2012). The Value Relevance of Corporate Voluntary Disclosure in the MiddleEast: The Case of Jordan. Journal of Accounting and Public Policy, 31(5), pp. 533-549.

Ammann, M., Oesch, D. and Schmid, M. M. (2011). Corporate Governance and Firm Value: International Evidence. Journal of Empirical Finance, 18(1), pp. 36-55.

Bailey, W., Karolyi, G.A. and Salva, C. (2006). The Economic Consequences of Increased Disclosure: Evidence from International Cross-listings. Journal of Financial Economics, 81(1), pp. 175-213.

Banghøj, J. and Plenborg, T. (2008). Value Relevance of Voluntary Disclosure in the Annual Report. Accounting and Finance, 48(2), pp. 159-180.

Benston, G.J. (1985). The Validity of Profits-Structure Studies with Particular Reference to the FTC's Line-ofBusiness Data. American Economic Review, 75(1), pp. 37-67.

Botosan, C.A. (1997). Disclosure Level and the Cost of Equity Capital. The Accounting Review, 72(3), pp. 323-349.

Botosan, C. and Plumlee, M. (2002). A Re-examination of Disclosure Level and the Expected Cost of Equity Capital. Journal of Accounting Research, 40(1), pp. 21-40.

Boubaker, S. and Labégorre, F. (2006). Informational Environment and Ownership Structure of Listed French Firms [In French]. Finance Contrôle \& Stratégie, 9(3), pp. 5-38.

Charnes, A., Cooper, W., Lewin, A. and Seiford, L. (1994). Data Envelopment Analysis: Theory, Methodology and Applications. Kluwer Academic Press.

Chau, G.K. and Gray S.J. (2002). Ownership Structure and Corporate Voluntary Disclosure in Hong Kong and Singapore. International Journal of Accounting, 37(2), pp. 247-265.

Cheung, Y.L., Jiang, P. and Tan, W. (2010). A Transparency Disclosure Index Measuring Disclosures: Chinese Listed Companies. Journal of Accounting and Public Policy, 29(3), pp. 259-280.

Cho, M. H. (1998). Ownership Structure, Investment, and the Corporate Value: An Empirical Analysis. Journal of Financial Economics, 47(1), pp. 103-21.

Cooke, T.E. (1992). The Impact of Size, Stock Market Listing and Industry Type on Disclosure in the Annual Reports of Japanese Listed Corporations. Accounting and Business Research, 22(87), pp. 229-237.

Demsetz, H. and Lehn, K. (1985). The Structure of Corporate Ownership: Causes and Consequences. Journal of Political Economy, 93(6), pp. 1155-1177.

Denis, D.J. and Denis, D.K. (1994). Majority Owner-managers and Organizational Efficiency. Journal of Corporate Finance. 1(1), pp. 91-118.

Dhaliwal, D.S., Li, O.Z., Tsang, A. and Yang, Y. G. (2011). Voluntary Nonfinancial Disclosure and the Cost of Equity Capital: The Initiation of Corporate Social Responsibility Reporting. The Accounting Review, 86(1), pp. 59-100.

Drobetz, W., Schillhofer, A. and Zimmermann, H. (2004). Corporate Governance and Expected Stock Returns: Evidence from Germany. European Financial Management, 10(2), pp. 267-93. 
Eng, L.L. and Mak, Y.T. (2003). Corporate Governance and Voluntary Disclosure, Journal of Accounting and Public Policy. 22(4), pp. 325-345.

Espinosa, M. and Trombetta, M. (2007). Disclosure Interactions and the Cost of Equity Capital: Evidence from Spanish Continuous Market. Journal of Business Finance \& Accounting, 34(9-10), pp. 1371-1392.

Francis, J., Nanda, D. and Olsson, P. (2008). Voluntary Disclosure, Earnings Quality, and Cost of Capital, Journal of Accounting Research. 46(1), pp. 53-99.

Gietzmann, M. and Ireland, J. (2005). Cost of Capital, Strategic Disclosures and Accounting Choice, Journal of Business Finance \& Accounting. 32(3-4), pp. 599-634.

Habib, M.A. and Ljungqvist, A. (2005). Firm Value and Managerial Incentives: A Stochastic Frontier Approach, Journal of Business. 78(6), pp. 2053-2094.

Hassan, M.S. and Mohd-Saleh, N. (2010). The Value Relevance of Financial Instruments Disclosure in Malaysian Firms Listed in the Main Board of Bursa Malaysia. International Journal of Economics and Management, 4(2), pp. 243-270.

Hassan, O.A., Romilly, P., Giorgioni, G. and Power, D. (2009). The Value Relevance of Disclosure: Evidence from the Emerging Capital Market of Egypt. The International Journal of Accounting, 44, pp. 79-102.

Healy, P.M. and Palepu, K. (2001). Information Asymmetry, Corporate Disclosure, and the Capital Markets: A Review of the Empirical Disclosure Literature. Journal of Accounting and Economics, 31(1-3), pp. 405440.

Himmelberg, C.P., Hubbard, R.G. and Palia, D. (1999). Understanding the Determinants of Managerial Ownership and the Link between Ownership and Performance: An Investigation of Share Ownership and Corporate Performance. Journal of Financial Economics, 53(3), pp. 353-384.

Holderness, C., Kroszner, R. and Sheehan, D. (1999). Were the Good Old Times that Good? Changes in Managerial Stock Ownership since the Great Depression. Journal of Finance, 54(1), pp. 435-469.

Holderness, C. and Sheehan, D. (1988). The Role of Majority Shareholders in Publicly Held Corporations: An Exploratory Analysis. Journal of Financial Economics, 20(1-2), pp. 317-347.

Holland, J.B. (1998). Private Disclosure and Financial Reporting. Accounting and Business Research, 28(4), pp. 255-269.

Jensen, M.C. and Meckling, W. (1976). Theory of the Firm: Managerial Behavior, Agency Costs and Ownership Structure, Journal of Financial Economics. 3(4), pp. 305-360.

Kalay, A. (1980). Signaling, Information Content, and the Reluctance to Cut Dividends. Journal of Financial and Quantitative Analysis, 15(4), pp. 855-869.

Karamanou, I. and Nishiotis, G.P. (2009). Disclosure and the Cost of Capital: Evidence from the Market's Reaction to Firm Voluntary Adoption of IAS. Journal of Business Finance and Accounting, 36(7-8), pp. 793-821.

Lajili, K. and Zéghal, D. (2006). Market Performance Impacts of Human Capital Disclosures. Journal of Accounting and Public Policy, 25(2), pp. 171-194.

Lang, M., Lins, K.V. and Miller, D.P. (2004). Concentrated Control, Analyst Following and Valuation: Do Analysts Matter Most When Investors are Protected Least? Journal of Accounting Research, 42(3), pp. 589-623.

Lang, M. and Lundholm, R. (1993). Cross-sectional Determinants of Analyst Ratings of Corporate Disclosures. Journal of Accounting Research, 31(2), pp. 246-271.

LaPointe, A.P., Cormier, D., Magnan, M. and Gay-Angers, S. (2006). On the Relationship Between Voluntary Disclosure, Earnings Smoothing and the Value relevance of Earnings: The Case of Switzerland. European Accounting Review, 15(4), pp. 465-505.

Li, M. and Simerly, R. (1998). The Moderating Effects of Environmental Dynamism on the Ownership and Performance Relationship. Strategic Management Journal, 19(2), pp. 169-179.

Lim, S., Matolcsy, Z. and Chow. D. (2007). The Association Between Board Composition and Different Types of Voluntary Disclosure. European Accounting Review, 16(3), pp. 555-583.

Meek, G.K., Roberts, C.B. and Gray, S.J. (1995). Factors Influencing Voluntary Annual Report Disclosures by U.S., U.K. and Continental European Multinational Corporations. Journal of International Business Studies, 26(3), pp. 555-572.

Miller, M.H. and Rock, K. (1985). Dividend Policy Under Asymmetric Information. Journal of Finance, 40(4), pp. 1031-1051.

Nanka-Bruce, D. (2009). Corporate Governance and Multi-Dimensional Performance. PhD Thesis, University of Barcelona. 
Neu, D., Warsame, H. and Pedwell, K. (1998). Managing Public Impressions: Environmental Disclosures in Annual Reports, Accounting Organisations and Society. 23(3), pp. 265-282.

Olsen, B. and Elango, B. (2005). Do Multinational Operations Influence Firm Value? Evidence from the triad Regions. International Journal of Business and Economics 4(1), pp. 11-29.

Oxelheim, L. and Randoy, T. (2003). The Impact of Foreign Board Membership on Firm Value. Journal of Banking and Finance, 27(12), pp. 2369-2392.

Pearson, N.D. (1992). Determinants of the Production of Information. Mimeo, University of Rochester.

Rockness, J. (1985). An Assessment of the Relationship Between US Corporate Environmental Performance and Disclosure. Journal of Business Finance and Accounting, 12(3), pp. 339-54.

Short, H. and Keasey, K. (1999). Managerial Ownership and the Performance of Firms: Evidence from the UK. Journal of Corporate Finance, 5(1), pp. 79-101.

Spence, M. (1973). Job Marketing Signalling. The Quarterly Journal of Economics, 87(3), pp. 355-374.

Thomsen. S. and Pedersen, T. (1996). Nationality and Ownership Structure: The 100 Largest Companies in Six European Nations. Management International Review, 36(2), pp. 149-166.

Thomsen, S. and Pedersen, T. (2000). Ownership Structure and Economic Performance in the Largest European Companies. Strategic Management Journal, 21(6), pp. 689-705.

Uyar, A. and Kiliç, M. (2012). Value Relevance of Voluntary Disclosure: Evidence from Turkish Firms, Journal of Intellectual Capital. 13(3), pp. 363-376.

Verrecchia, R.E. (1983). Discretionary Disclosure. Journal of Accounting and Economics, 5, pp. 365-380.

Verrecchia, R.E. (2001). Essays on Disclosure. Journal of Accounting and Economics, 32, pp. 97-180.

Zarb, B.J. (2007). Voluntary Disclosures of Forward-looking Earnings Information and Firm Value in the Airline Industry. International Journal of Business Research, 7(6), pp. 1-19. 
APPENDIX: Checklist Of Voluntary Disclosure

\begin{tabular}{|c|c|c|c|}
\hline Checklist Of Items & References & Checklist Of Items & References \\
\hline A - Strategic information & & 30. Description of capital project committed & $\mathrm{A}, \mathrm{B}, \mathrm{C}$ \\
\hline $\begin{array}{l}\text { A1. General information about the } \\
\text { Firm }\end{array}$ & & B - Non-financial information & \\
\hline 1. Brief history of the company & $\mathrm{A}, \mathrm{B}, \mathrm{C}, \mathrm{E}$ & B1. Employee information & \\
\hline 2. General description of the business & $\mathrm{B}, \mathrm{D}$ & 1. Geographical distribution of employees & $\mathrm{A}, \mathrm{C}$ \\
\hline 3. Main products & $\mathrm{B}, \mathrm{D}$ & 2. Number of employees by gender & $\mathrm{A}, \mathrm{C}$ \\
\hline 4. Main markets & $\mathrm{B}, \mathrm{D}$ & 3. Number of employees by age & $\mathrm{A}, \mathrm{C}$ \\
\hline A2. Corporate strategy & & 4. Categories of employees by function & $\mathrm{A}, \mathrm{C}$ \\
\hline 5. Statement of the main objectives & $\mathrm{A}, \mathrm{B}, \mathrm{C}, \mathrm{D}, \mathrm{E}$ & $\begin{array}{l}\text { 5. Number of employees for two or more } \\
\text { years }\end{array}$ & $\mathrm{A}, \mathrm{C}, \mathrm{E}$ \\
\hline 6. Statement of the financial objectives & $\mathrm{A}, \mathrm{C}, \mathrm{E}$ & 6. Average compensation per employee & A, B \\
\hline 7. Current strategy & $\mathrm{A}, \mathrm{B}, \mathrm{C}, \mathrm{F}$ & 7. Added value per employee & $\mathrm{A}, \mathrm{B}$ \\
\hline 8. Impact of strategy on current results & $\mathrm{B}$ & 8. Data productivity & $\mathrm{A}, \mathrm{B}, \mathrm{C}$ \\
\hline 9. Future strategy & $\mathrm{A}, \mathrm{B}, \mathrm{C}$ & 9. Safety policy & $\mathrm{A}, \mathrm{B}, \mathrm{C}$ \\
\hline 10. Impact of strategy on future results & $\mathrm{A}, \mathrm{C}, \mathrm{E}$ & 10. Cost of safety measures & $\mathrm{A}, \mathrm{C}$ \\
\hline A3. $R \& D$ activities & & 11. Data on accidents & $\mathrm{A}, \mathrm{C}, \mathrm{E}$ \\
\hline 11. Description of R\&D projects & $\mathrm{A}, \mathrm{C}$ & 12. Policy on communication & $\mathrm{A}, \mathrm{C}$ \\
\hline 12. Corporate policy on R\&D & $\mathrm{A}, \mathrm{C}$ & 13. Redundancy information & $\mathrm{A}, \mathrm{C}$ \\
\hline 13. Location of $R \& D$ activities & A, C, D & $\begin{array}{l}\text { 14. Reason for changes in employee numbers } \\
\text { or categories over time }\end{array}$ & $\mathrm{A}, \mathrm{C}$ \\
\hline 14. Number employed in R\&D & $\mathrm{A}, \mathrm{C}, \mathrm{E}$ & 15. Recruitment problems and related policy & $\mathrm{A}, \mathrm{C}$ \\
\hline $\begin{array}{l}\text { A4. Analysis and discussion of } \\
\text { management review of projects }\end{array}$ & & B2. Information about the training policy & \\
\hline 15. Review of operations & $\mathrm{B}$ & 16. Amount spent in training programs & $\mathrm{A}, \mathrm{C}, \mathrm{E}$ \\
\hline 16. Competitive environment & $\mathrm{B}, \mathrm{D}$ & 17. Nature of training & $\mathrm{A}, \mathrm{C}, \mathrm{E}$ \\
\hline 17. The most significant events & $\mathrm{B}, \mathrm{D}$ & 18. Policy on training & $\mathrm{A}, \mathrm{C}, \mathrm{E}$ \\
\hline 18. Change in sales and profits & $\mathrm{B}, \mathrm{D}$ & 19. Categories of employees trained & $\mathrm{A}, \mathrm{C}, \mathrm{E}$ \\
\hline 19. Change in cost of goods sold & $\mathrm{B}, \mathrm{D}$ & $\begin{array}{l}\text { B3. Social policy and value-added } \\
\text { information }\end{array}$ & \\
\hline 20. Change in expenses & $\mathrm{B}, \mathrm{D}$ & 20. Safety of products & $\mathrm{A}, \mathrm{C}$ \\
\hline 21. Change in inventory & $\mathrm{B}, \mathrm{D}$ & 21. Program of environmental protection & $\mathrm{A}, \mathrm{C}, \mathrm{E}$ \\
\hline 22. Change in share price & $\mathrm{B}, \mathrm{D}$ & 22. Charitable donations & $\mathrm{A}, \mathrm{C}, \mathrm{E}$ \\
\hline A5. Future prospects & & 23. Community programs & $\mathrm{A}, \mathrm{C}, \mathrm{E}$ \\
\hline 23. Future development channels & $\mathrm{A}, \mathrm{B}, \mathrm{C}$ & 24. Value-added data & $\mathrm{A}, \mathrm{C}, \mathrm{E}$ \\
\hline 24. Qualitative forecast of sales & $\mathrm{A}, \mathrm{B}, \mathrm{C}, \mathrm{E}$ & 25. Value-added ratios & $\mathrm{A}, \mathrm{C}, \mathrm{E}$ \\
\hline 25. Quantitative forecast of sales & $\mathrm{A}, \mathrm{B}, \mathrm{C}, \mathrm{D}, \mathrm{F}$ & 26. Qualitative value-added information & $\mathrm{A}, \mathrm{C}, \mathrm{E}$ \\
\hline 26. Qualitative forecast of profits & $\begin{array}{l}\text { A, B, C, D, } \\
\text { E, F }\end{array}$ & B4. Segmental information & \\
\hline 27. Quantitative forecast of profits & $\mathrm{A}, \mathrm{B}, \mathrm{C}, \mathrm{E}$ & $\begin{array}{l}\text { 27. Geographical distribution of invested } \\
\text { capital }\end{array}$ & $\mathrm{A}, \mathrm{C}, \mathrm{E}$ \\
\hline 28. Assumptions underlying the forecasts & $\mathrm{A}, \mathrm{B}, \mathrm{C}$ & 28. Geographical distribution of net assets & $\mathrm{A}, \mathrm{C}$ \\
\hline 29. Review of forecasts & $\mathrm{A}, \mathrm{B}, \mathrm{C}$ & & \\
\hline
\end{tabular}


Checklist of voluntary disclosure (continued)

\begin{tabular}{|c|c|c|c|}
\hline Checklist Of Items & References & Checklist Of Items & References \\
\hline 29. Geographical distribution of production & $\mathrm{A}, \mathrm{C}, \mathrm{E}$ & 21. Estimates of capital increase & $\mathrm{A}, \mathrm{B}, \mathrm{C}$ \\
\hline 30. Expenditure on the business lines & $\mathrm{A}, \mathrm{C}$ & 22. Earnings estimates & $\mathrm{A}, \mathrm{B}, \mathrm{C}$ \\
\hline 31. Revenue by business line & A, C & $\begin{array}{l}\text { 23. Effect of inflation currency fluctuations on } \\
\text { future operations }\end{array}$ & $\mathrm{A}, \mathrm{C}$ \\
\hline 32. Competitor analysis - quantitative & $\mathrm{A}, \mathrm{C}$ & $\begin{array}{l}24 \text {. Effect of currency fluctuations of interest } \\
\text { rates on future operations }\end{array}$ & $\mathrm{A}, \mathrm{C}$ \\
\hline 33. Competitor analysis - qualitative & $\mathrm{A}, \mathrm{C}$ & C4. Information on exchange rates & \\
\hline 34. Market share analysis - quantitative & A, C & $\begin{array}{l}\text { 25. Impact of currency fluctuations on current } \\
\text { results }\end{array}$ & $\mathrm{A}, \mathrm{B}, \mathrm{C}$ \\
\hline 35. Market share analysis - qualitative & A, C & $\begin{array}{l}\text { 26. Impact of currency fluctuations on future } \\
\text { operations }\end{array}$ & $\mathrm{A}, \mathrm{C}, \mathrm{E}$ \\
\hline C-Financial information & & 27. Estimates of currency fluctuations & $\mathrm{A}, \mathrm{B}, \mathrm{C}$ \\
\hline $\begin{array}{l}\text { C1. Performance indicators (not included } \\
\text { in the financial statements) }\end{array}$ & & 28. Exchange rates used in accounting & $\mathrm{A}, \mathrm{B}, \mathrm{C}$ \\
\hline 1. Performance indicators & $\mathrm{A}, \mathrm{B}, \mathrm{C}$ & 29. Long-term debt by currency & $\mathrm{A}, \mathrm{C}$ \\
\hline 2. Financial data for the last five years & $\begin{array}{c}\mathrm{A}, \mathrm{B}, \mathrm{C}, \mathrm{D} \\
\mathrm{E}\end{array}$ & 30. Short-term debt by currency & A, C \\
\hline 3. Turnover & $\begin{array}{c}\mathrm{A}, \mathrm{B}, \mathrm{C}, \mathrm{D} \\
\mathrm{F}\end{array}$ & C5. Other financial information & \\
\hline 4. Net income & $\begin{array}{c}\mathrm{A}, \mathrm{B}, \mathrm{C}, \mathrm{D} \\
\mathrm{F}\end{array}$ & 31. Share price at year end & A, C \\
\hline 5. Shareholders' equity & $\mathrm{A}, \mathrm{B}, \mathrm{C}, \mathrm{D}$ & 32. Share prices trend & $\mathrm{A}, \mathrm{C}, \mathrm{E}$ \\
\hline 6. Total assets & $\begin{array}{c}\mathrm{A}, \mathrm{B}, \mathrm{C}, \mathrm{D} \\
\mathrm{F}\end{array}$ & 33. Market capitalization at year end & $\mathrm{A}, \mathrm{C}, \mathrm{E}$ \\
\hline 7. Earnings per share & $\mathrm{A}, \mathrm{B}, \mathrm{C}$, & 34. Trend of market capitalization & $\mathrm{A}, \mathrm{C}$ \\
\hline 8. Dividend payout policy & $\mathrm{A}, \mathrm{B}, \mathrm{C}$ & 35. Size of shareholdings & $\mathrm{A}, \mathrm{C}$ \\
\hline 9. Transfer pricing policy & $\mathrm{A}, \mathrm{B}, \mathrm{C}$ & 36. Forecast market share & $\mathrm{A}, \mathrm{C}, \mathrm{D}, \mathrm{F}$ \\
\hline $\begin{array}{l}\text { 10. Impact of any accounting policy } \\
\text { changes on results }\end{array}$ & $\mathrm{A}, \mathrm{B}, \mathrm{C}$ & D- Governance information & \\
\hline 11. Advertising expenditure & $\mathrm{A}, \mathrm{B}, \mathrm{C}, \mathrm{E}$ & 1. Ownership structure & A, C \\
\hline 12. Effect of inflation on results & $\mathrm{A}, \mathrm{B}, \mathrm{C}$ & 2. Organizational chart & $\mathrm{A}, \mathrm{B}, \mathrm{C}, \mathrm{E}$ \\
\hline 13. Effect of inflation on assets & $\mathrm{A}, \mathrm{B}, \mathrm{C}$ & Composition of the board of directors & \\
\hline $\begin{array}{l}\text { 14. Effect of fluctuating interest rates on } \\
\text { results }\end{array}$ & $\mathrm{A}, \mathrm{B}, \mathrm{C}, \mathrm{E}$ & 3. Personal profiles & A, C \\
\hline C2. Financial ratios & & 4. Descriptions of the positions occupied & $\mathrm{A}, \mathrm{C}$ \\
\hline 15. Liquidity ratio & $\mathrm{A}, \mathrm{B}, \mathrm{C}, \mathrm{E}$ & 5. Length of time belonging to the company & $\mathrm{A}, \mathrm{B}, \mathrm{C}$ \\
\hline 16. Turnover ratio of assets & $\mathrm{A}, \mathrm{B}, \mathrm{C}$ & $\begin{array}{l}\text { 6. Number of shareholders sitting on the board } \\
\text { of directors }\end{array}$ & $\mathrm{A}, \mathrm{B}, \mathrm{C}$ \\
\hline 17. Debt ratio & $\mathrm{A}, \mathrm{B}, \mathrm{C}, \mathrm{E}$ & 7. Academic profile of the directors & $\mathrm{A}, \mathrm{B}, \mathrm{C}$ \\
\hline 18. Profitability ratios & $\begin{array}{c}\mathrm{A}, \mathrm{B}, \mathrm{C}, \mathrm{E} \\
\mathrm{F}\end{array}$ & 8. Presence of an Internal Audit Committee & $\mathrm{A}, \mathrm{B}, \mathrm{C}$ \\
\hline 19. Other useful ratios & $\mathrm{A}, \mathrm{B}, \mathrm{C}, \mathrm{E}$ & 9. Age of the executives & $\mathrm{A}, \mathrm{B}, \mathrm{C}$ \\
\hline C3. Forecast information & & 10. Profile of the executives & $\mathrm{A}, \mathrm{B}, \mathrm{C}$ \\
\hline 20. Cash flow forecast & $\mathrm{A}, \mathrm{B}, \mathrm{C}, \mathrm{D}$ & 11. Individual remuneration & $\mathrm{A}, \mathrm{B}, \mathrm{C}$ \\
\hline
\end{tabular}

A: Meek et al. (1995).

B: Eng and Mak (2003).

C: Chau and Gray (2002).

D: Botosan (1997).

E: Lim et al. (2007).

F: Francis et al. (2008). 